\title{
A Case Study in Daily Operatic Practice Around 1900 In a Prologue, Six Vignettes and an Epilogue, or: Pfitzner Produces Parsifal.
}

\author{
by \\ Jeroen van Gessel
}

\section{Prologue}

Books about opera abound. There are studies of individual operas, histories of opera houses, biographies of singers, impresarios, composers and directors, studies on aesthetic currents, on politics, performance practice and other aspects related to opera in some way or the other. It is rare, however, to see all these strands brought together. The obvious reason for this seems to be the daunting complexity of such a task. If all relevant context has to be taken into account, how can it be structured and, more importantly, what strategies are available for assessing what actually is relevant.

This essay is an attempt at such a combination, using a structure that is loosely based on principles of the system theory of the German sociologist Niklas Luhmann. The basic tenet of his theory is that society is created by communication. These communications can, through a series of events we will bypass for the moment, create a certain 'differentiated' communication system that is self-operative, meaning that it creates its own structure for communication within the system as well as the communications themselves. Finance is such a system, as is law or art or opera. These systems, while self-operative, maintain relations with the outside world and define themselves with reference to the outside world by their distinction.

Such a short summary inevitably borders on caricature, but the main point here is to seek out why some aspects of this theory may be a useful tool for researching operatic practice.

One of the first reasons is that the system theory does not assume a world view that starts with the whole and seeks specialization through endless subdivision. It does not assume that any form of communication or any system is expected to be in contact with all 
other communications or communication systems. On the contrary, most communications take place within differentiated systems, which have created themselves through communications and built up specific structures for them. Thus system theory is an effective tool for deciding which communication with other systems (context) is actually relevant, since constant communication with all other systems - all systems equaling society as a whole - never occurs.

This brings us to the second reason. Since the basic unity is communication between systems, there is no primordial direction. The art work no longer functions as the goal of introductory chapters that seek to create the basis for comprehension by providing context, nor is the performance a mere addition to a finished composition or the press simply an institution at the end of the process, finishing a chain of events through the publication of a review. All systems may communicate with other systems at some point, making cross contacts at any time. (In ordering the vignettes below I was no doubt influenced by traditional narrative, but the order is not a hierarchy.)

Finally, a strong, differentiated system can maintain its own structure of communication even when faced with communications from other different systems that might be disruptive. (Paying a judge to influence his discretion may disrupt the legal process - go against the legal system's structures for communication — but it is unlikely to bring down the entire legal system. Likewise, a politician influencing the operatic schedule of a theatre, may disrupt artistic communication, but cannot destroy art, nor cause the works performed at his behest to become non-art, as long as the differentiated system 'art' has strong selfreferential communications, which has been the case for at least the last two centuries.) Therefore, one may study the influence of political, financial and other systems without fear of 'losing' the art work.

All this may seem rather abstract. In order to clarify how these deliberations may be applied to research of daily operatic practice this essay focuses on one single opera production: the Strasbourg premiere of Wagner's Parsifal, directed and conducted by Hans Pfitzner. The various elements that in one way or another determined its character will be analysed. I will start with the building that housed the Strasbourg theatre, proceed with political and economic aspects, followed by the audience and the artists. Then I will discuss aspects of the performance, before continuing with the press. Finally, some 
thoughts will be offered on the usefulness of this particular strategy.

\section{First Vignette. The Building: Exterior and Interior}

The theatre that now stands at the Place Broglie in Strasbourg is a copy of its predecessor, a building that was inaugurated in 1821 after a rather protracted history of designing and redesigning that had lasted some twenty years. ${ }^{1}$ Due to the bombing of Strasbourg during the Franco-Prussian War, the theatre was destroyed by fire on 10 September 1870. After the annexation of the Alsace-Lorraine and its incorporation in the new German empire as the so-called 'Reichsland', the new German authorities decided to completely reconstruct the heavily damaged western and northern part of the city and to build exact replicas of the architecturally most articulate buildings. It was meant as a gesture of reconciliation to the population, after inspections conducted directly following the French surrender had revealed a hitherto unknown level of destruction of civilian property. ${ }^{2}$ Reconstruction work was finished in 1872 and in 1873 the theatre opened its doors for the first season of German performances. ${ }^{3}$

The conciliatory gesture to build a replica of the original building might have made sense from the political point of view, that pacification of the local population was the first priority, but it firmly put the theatre out of touch with the new realities of German rule that found expression in the construction of a new district, directly behind the theatre and just across the canal. It featured an imperial palace, situated at the 'imperial square' ('Kaiserplatz'), where it was joined by an equally new parliament and a university library. The latter two flanked a broad boulevard that connected the 'imperial square' with the 'university square', which, predictably, was dominated by the monumental new university building. Although slightly different in architectural style, with the imperial palace a notable exception, these edifices were supposed to articulate a grandeur that would ferment Strasbourg's status as the capital of new German territory and show that the German

\footnotetext{
1. For a detailed account of the building history, see Geneviève Levallet-Haug, 'Histoire architecturale du théâtre de Strasbourg', Archives Alsaciennes d'histoire de l'art, 14 (1935): 257-312.

2. Klaus Nohlen, Baupolitik im Reichsland Elsaß-Lothringen 1871-1918. Die repräsentativen Staatsbauten um den ehemaligen Kaiserplatz in Straßburg (Berlin: Mann, 1982): 27-29.

3. Myriam Geyer, La vie musicale à Strasbourg sous l'empire allemand (1871-1918) (Paris :École des Chartes, 1999), 101-102.
} 
occupation was not just a transitory phenomenon. A fitting architectural style, in combination with the grandiose scope of the buildings (size did matter), should drive this point home convincingly. Whatever that style might be, building authorities insisted that it should in no way be reminiscent of Strasbourg's ancient buildings, because that would imply aligning to their 'French orientation'. ${ }^{4}$ Standing in the ancient town centre, the neoclassical theatre with its pointed roof - $\mathrm{a}$ feature also present in the original plans for the new university building, only to be subsequently modified, because it was considered not German $^{5}$ - and its six-pillar facade, seemed to hold itself both topographically and stylistically aloof of the new political developments.

The interior soon posed problems of its own. There is no complete certainty about the degree of accuracy with which it was rebuilt. A so-called 'Ortsbeschreibung', undated, but presumably compiled shortly after the restoration was completed, confines itself to listing the rooms on the various floors with some indication of the materials used. ${ }^{6}$ Apart from the entree, foyer, auditorium, stage, attic, cellar, the caretaker's quarters and some other utility rooms the list mentions some thirty-odd other rooms, which could be used by the administration and the artistic personnel. It soon transpired that these facilities were insufficient. Following the catastrophic fire at the Salle Favart, home to the Paris Opéra comique, on 25 May 1887, a thorough inspection of security measures in the Strasbourg theatre was carried out by a committee, chaired by Gustave Fischbach, an ardent music lover and 'Beigeordneter' (a direct assistant to the mayor, comparable to an alderman). Whereas security measures for the audience were by and large sufficient, the committee was appalled to learn that the cramped conditions behind the stage would almost certainly result in heavy casualties in case of fire. ${ }^{7}$ The problem was solved by enlarging the back of the theatre with a semi-circular extension, providing more space for the artistic personnel. Their safety also improved thanks to an increased number of exits.

Over the years it became increasingly clear that the well-intended resurrection of the

\footnotetext{
4. Nohlen, Baupolitik im Reichsland Elsaß-Lothringen 1871-1918, 108-109.

5. Godehard Hoffmann, Architektur für die Nation? Der Reichstag und die Staatsbauten des Deutschen Kaiserreichs 1871-1918 (Cologne: DuMont, 2000), 165.

6. Strasbourg Municipal Archives (hereafter SMA) 180MW, Nr. 201.

7. See Bauliche Änderungen im Stadttheater. Bericht an den Staatsuntersecretär Back, Bürgermeister der Stadt Strassburg. Vorgetragen in der Sitzung vom 29. Juni 1887 von dem Herrn Beigeordneten Fischbach (Strasbourg: Fischbach, 1887).
} 
ancient theatre had all the makings of a Trojan horse. Quick changing of sets was impossible due to the outdated machinery, causing a constant stream of complaints from the audience about the drawn out intermissions. Lack of space meant that the sets could neither be produced nor properly stored in the theatre, necessitating the use of other property in the area. This in turn proved detrimental to all stage materials, which had to be transported continuously to and from the theatre. The materials that were stored backstage prevented the installation of more sophisticated stage machinery, which made it increasingly difficult to keep up with contemporary developments in staging techniques. During the Parsifal performances the cramped conditions backstage caused problems as well. Because there was no place for four church bells in the orchestra pit or the rooms below and back stage, these were placed in the attic above stage, each one two meters apart from the next. An electrical light signal was installed with a corresponding button on the rostrum, so that Pfitzner could signal the cues by pressing a button, but he mostly forgot. As a result the two students playing the bells found themselves in a dark room, from where they could not see the conductor and hardly heard the music. A vocal score in their hand, they would scurry from one bell to another, signalling to each other when the next note was to be played. ${ }^{8}$

To make matters worse, the theatre also displayed symptoms of being a 'sick building'. The gas heating created a stifling atmosphere, but could not be missed, because stage lighting was too weak to illuminate the stage properly. The introduction of electric light brought only a slight improvement. Another unfortunate consequence of the zeal to restore the original was the building material that had been used. Most of the floors on the ground level were made out of sandstone and such a relatively soft type of stone displayed an extraordinary potential for causing a dusty atmosphere. Each time the audience entered the auditorium they carried the dust from the floor along with them, which meant that the entire room was filled with a dusty fog. Not only, as one director once remarked, did it cause the often dark attire of the audience to look like it was sprayed with flour, it also was quite uncomfortable for the performers to find themselves addressing a cloud of dust, immediately after the curtain was raised. ${ }^{9}$ Their plight was made no better by the distance

\footnotetext{
8. Chris Walton, ed., Czesław Marek. Komponist, Pianist, Pädagoge (Winterthur: Amadeus, 1999), 98-100.

9. Joseph Engel (Director from 1900 till 1903), '[Rapport] Betr. Bauliche Veränderungen im Stadttheater',
} 
from stage to dressing rooms, which could be reached only by a flight of stairs consisting of 32 steps. The principal characters, in particular, had to climb it up to six times during the performance in order to change. Often soaked by perspiration due to the heat in the auditorium and the effort of their performance, they were not only confronted with these stairs, but also by the lower temperature backstage. Neither were they safe from cold draughts on stage. These were often caused by backstage doors being opened, which inevitably happened quite regularly when sets were changed, since they could not all be stored inside the theatre.

A steady stream of repairs kept things going, but it became increasingly clear that the theatre's structural problems required more permanent solutions. In 1913 four architects were invited to submit plans; three of them recommended constructing an entirely new theatre. Faced by the estimated cost of three to four million Marks, a more modest plan for restructuring was selected, submitted by the Cologne architect Carl Moritz, who had designed a number of new theatres. ${ }^{10}$ The outbreak of the Great War prevented any large scale reconstruction work and from 1919 to 1940, when Strasbourg had been returned to France, lack of money had the same effect. Only after the Nazi takeover did the Strasbourg theatre finally witness extensive restructuring and modernization. The work was carried out on the express wishes of none other than Adolf Hitler. ${ }^{11}$

\section{Second Vignette. Politics: Administration and Ideology}

After its reconstruction, the theatre was managed for three years as 'kaiserlich concessionirtes Theater zu Strassburg', that is, under the protection of the imperial governor (kaiserlicher Statthalter) of the Reichsland. In 1876 responsibility was handed over to the municipal authorities, who chose, as was usual at the time, to lease the theatre

\footnotetext{
dated 10 May 1900; SMA 180MW, Nr. 23.

10. The plan is mentioned in the minutes of the Theatre commission, but has not been preserved. Meeting of the theatre committee, 9 January 1913; SMA 180MW, Nr. 26.

11. This follows on from a letter from Albert Speer to Fritz Todt, dated 28 February 1941. It accompanied a request for 250 tons of steel for reconstruction of the Strasbourg theatre. Speer appeals to grant this request with the following observation: 'Der Führer liess sich nach meinem Besuch in Strassburg über den Zustand des Theaters ausführlich berichten und wünschte damals eine Erneuerung dieses Hauses. Ich glaube daher, dass es auch dem Wunsch des Führers entspricht, wenn das Eisen nach Möglichkeit zur Verfügung gestellt wird.' SMA 7MW, Nr. 371.
} 
to theatrical entrepreneurs. In return for a fixed sum, they guaranteed a certain number of performances according to guidelines provided by the municipal authorities. The building and the municipal orchestra were placed at their disposal. ${ }^{12}$ In 1886 , this situation came to an end quite unexpectedly. During the third season of his contractual term, director Hermann Temmel notified the municipal council that he had lost all credit with the audience. The working conditions in the theatre had taken their toll: a number of the artist had fallen ill, causing continuous changes to the schedule of play, before it finally came to an almost complete standstill. If he were to carry on, Temmel feared total bankruptcy. ${ }^{13}$ Fischbach argued that the only option now was to bring the theatre under direct control of the municipal authority. The municipal council adopted his view, albeit with general reluctance and at that time just as a temporary measure.

It soon became clear that the new direct form of administration was a rather tiresome affair, because all decisions concerning the theatre, like buying new works or stage materials or engaging new personnel, had to be brought before the council. In 1887, a special theatre committee was formed to relieve this burden. ${ }^{14}$ From now on all decisions concerning the theatre had to be ratified by the theatre committee or, when larger sums of money were involved, the municipal council. In theory the theatre committee only had to monitor the theatre's financial situation and could do so because from now on the theatre director was stripped of all power to make decisions on his own. Regardless of whether he wanted to renew a contract with a publisher for hired orchestral parts, buy new furniture for the staging of a certain opera, pay some extra money to a chorus member who had helped with copying parts, or acquire the rights to a new opera, he always had to obtain the committee's consent. Engaging artists not only required the committee's consent, but also the mayor's approval.

During the first years the committee consisted of only four members-including the mayor-but after 1900 it steadily expanded, numbering about fifteen members. The numerical growth accompanied a gradual increase in the scope of the committee's

\footnotetext{
12. Geyer, La vie musicale, 103-109.

13. Meeting of the municipal council, 27 October 1886; SMA 1MW222 (Verhandlungen des Gemeinderats der Stadt Strassburg 1886, 538-547).

14. Meeting of the municipal council, 21 September 1887; SMA 1MW223 (Verhandlungen des Gemeinderats der Stadt Strassburg 1887), 828-835.
} 
involvement. Originally the committee's duty was interpreted strictly along the lines of financial control, with the unspoken intention of curbing any overly enthusiast spending by the director. It did not take long for the members to realise that now they could also directly influence artistic policy, indeed to become co-authors of artistic practice. This included urging the director to programme certain plays or operas, to contract certain singers contrary to his wishes or to assign roles to certain singers. Yet the committee was not just a bureaucratic establishment; it had its own loge in the theatre, which it used frequently, thereby keeping tabs on performance standards and audience reaction.

Rather surprisingly, until about 1900 the idea that the theatre could be used as an aid to the general political agenda of Germanising the Reichsland never seems to have gained much prominence. When, in 1873, Alexander Hessler was appointed director of the theatre by the 'Oberpräsident' of the Reichsland, Eduard von Möller, the former recognized the ramifications of his duties. In 1879 he wrote an assuring letter to Möller, quoting the latter's instruction to be aware of "the special importance of a German stage for fostering a taste for German music and poetry in the Alsace-Lorraine", but forgot to mention that he had mounted plays in French as well, as a matter of fact on the specific orders of Von Möller himself. ${ }^{15}$ The decision to take direct control of the theatre had never been a politically motivated one and in the minutes there is little or no evidence that it seems to have been very much on the committee's mind.

This may have been due to personal factors. Strasbourg's first mayor, Otto Back, adopted a rather impassive stand on all theatre matters. When in 1886 Fischbach ardently argued that as a municipal city with a population of over one hundred thousand Strasbourg simply could not afford not to have a theatre, his stance was principally that of the passionate music lover. Maybe he had political considerations in the back of his mind as well, but he refrained from expressing them articulately and did not even bother to pay lip service to them. Back, on the other hand, simply concluded that the takeover was probably inevitable, but added that he personally felt that it would be better if the municipal authority abstained from this burden. ${ }^{16}$ He later added that, with only a relatively small

\footnotetext{
15. Hessler to Möller, 1 December 1879; Strasbourg Departmental Archives (hereafter: SDA), 71AL193.

16. Meeting of the municipal council, 27 October 1886; SMA 1MW222 (Verhandlungen des Gemeinderats der Stadt Strassburg 1886), 538-547.
} 
number of inhabitants taking an interest in the theatre, spending an inevitably disproportionate part of the city's tax revenues made him feel rather uncomfortable. ${ }^{17}$ His successor, Rudolf Schwander, took a rather different view. A tireless and energetic personality, with an unmistakable panache for managing large-scale projects, Schwander displayed a deep personal interest in the theatre, while maintaining the detached judgement of the trained administrator. Back's management of the theatre was hands off, Schwander's was hands on. Where Back often did not bother to attend the meetings of the theatre committee and was content to let Fischbach chair them even in his presence, Schwander immediately took direct and personal control. He initiated two reorganisations (1907 and 1913) of the theatre's working structure and kept a close eye on everything that went on in the theatre. His ambition to see it prosper both artistically and financially occasionally became somewhat obsessive. On one occasion he even complained about newly purchased waste paper baskets, because they had cost 3,40 Mark, whereas those used in the town hall had been bought for only 1,50 Mark. ${ }^{18}$

Although Schwander, like his predecessor, never felt the need to boast about the theatre's political importance, he seems to have been more aware of it. In a letter to an army officer, who complained about a lack of nationalistic plays in the theatre's program during the Great War, Schwander stressed that he had always considered the theatre's main duty to propagate 'Deutschtum' in the Alsace and voiced this opinion regularly during meetings of the theatre committee. ${ }^{19}$ The theatre's programming in general and his orders to schedule cycles of classic German plays, he argued, proved this beyond any doubt. Neither of these claims is supported by the minutes of the theatre committee's meetings, but it is undoubtedly true that Schwander on occasion gave direct orders for the production of some pieces.

In general, hiring artistic directors with a clear penchant for German culture was more effective than intervening personally, and this consideration may have caused Schwander to back Hans Pfitzner's appointment as opera director. He had been appointed head of the Strasbourg conservatory in September 1907, on the condition that in the near future he

\footnotetext{
17. Meeting of the municipal council, 21 September 1887; SMA 1MW223 (Verhandlungen des Gemeinderats der Stadt Strassburg 1887), 1036-1037.

18. Schwander to Wilhelmi, 5 October 1910; SMA 180MW, Nr. 15.

19. Schwander to J.V. von Vietinghoff-Scheel, 9 March 1915; SMA 180MW, Nr. 16.
} 
would also be employed at the theatre. Schwander had agreed. Yet nothing of this was made public and with good reason, because there was no such vacancy at the theatre. What followed was an exemplary exercise in shrewd administration. When a few months later the theatre committee suggested that the principal conductor, Albert Gorter, be replaced and that Pfitzner be consulted about a suitable candidate, the latter, no doubt prompted by Schwander, instead presented plans for a reorganisation that would feature, among other things, appointing himself as head of opera productions ('Operndirektor') with an annual salary of 2.500 Mark. $^{20}$ Schwander then relayed these ideas to the committee and vigorously defended them. ${ }^{21}$ The committee, though somewhat reluctantly, agreed, except on Pfitzner's salary. When the contract with Gorter, who had successfully negotiated a one year prolongation of his contract just before Pfitzner's plan had been approved by the committee, finally expired after the season 1909-1910, Pfitzner was officially appointed head of opera productions on 12 April 1910. Nevertheless, the theatre committee had stipulated that for this post he would receive no additional payment to his salary as director of the conservatory. ${ }^{22}$ The productions that Pfitzner mounted during his first two seasons proved to be enormously successful and that prompted the committee to ask for an increased frequency of Pfitzner's performances. Schwander then took this as a cue to point out that Pfitzner, should he be prepared to do this, was entitled to extra salary. When the committee then reminded him that Pfitzner had agreed to accept this post without such conditions, Schwander played a trump card. He said that Pfitzner had already been paid over the last two years out of private funds that he, Schwander, had raised on his behalf. ${ }^{23}$ Now the committee had no way out. Faced with their own wishes for increased involvement by Pfitzner and the fact that he already had been paid for his work, they had no alternative but to agree that from now on Pfitzner would receive an annual salary of 4.000 Mark. And thus Schwander's cunning tactics had succeeded in securing Pfitzner his desired post, for which there initially was no vacancy, and to award him a salary that the committee initially never would have agreed to.

Schwander could not only help people into office, he was also an expert in getting rid of

\footnotetext{
20. Meeting of the theatre committee, 9 December 1907; SMA 180MW, Nr. 24.

21. Meeting of the theatre committee, 8 May 1908; SMA 180MW, Nr. 24.

22. Schwander to Pfitzner, 12. April 1910; SMA 180MW, Nr. 71.

23. Meeting of the theatre committee, 22 November 1912; SMA 180MW, Nr. 26.
} 
those he considered incompetent. His most high profile victim was Maximilian Wilhelmi. By training an actor who had been engaged in Strasbourg as such since 1893, he had been promoted to general director in 1903. Schwander's predecessor, Back, had had no qualms about Wilhelmi's ability to run the theatre, but Schwander soon lost patience with him. From about 1910 Wilhelmi's desk was inundated with advices, reproaches, and directives from Schwander. In November 1912, Schwander finally told Wilhelmi that he had better petition early retirement, which he did accordingly. ${ }^{24}$ It turned out to be a catastrophic decision. Not only would it cost the city 100.000 Mark, because Wilhelmi's long-time service had earned him the status of public official — though luckily, from a financial point of view, he died within three months of his resignation- but also because his successor, Anton Otto, did not develop the cordial working relationship with Pfitzner that Wilhelmi had had. It was in fact the very inability of the two to work together fruitfully and harmoniously that caused the committee to abandon Pfitzner's and Otto's engagement in 1916, although in the end the latter was allowed to stay, because the committee feared that finding a successor during the war would prove to be impossible.

Direct involvement from the mayor was a major factor in determining how the theatre was run, but it would be a mistake to underestimate the importance of the theatre committee. As a delegate of the municipal council it could also put its stamp on theatrical practice, something Pfitzner would realize soon enough and also in relation to his production of Parsifal.

\section{Third Vignette. Money: Expenses and Returns}

Considering that the city's direct oversight of the theatre through the committee was instigated primarily to control spending, it is safe to say that the committee did not do a particularly good job. In fact, soon after, the city's takeover cost started to spiral out of control. Partly responsible was the municipal council itself. ${ }^{25}$ In 1890 , the composer Viktor Nessler, a native from the Alsace, sent the municipal council and the mayor a copy of his latest piece, Die Rose von Straßburg, an opera featuring a shooting competition held in

\footnotetext{
24. Ibid.

25. Nessler to Back, 7 March 1890; SMA 180MW, Nr. 12.
} 
Strasbourg in 1576. The piece required lavish sets and costumes, which would cost about 6.000 Mark. Even Back, openly hesitant about spending much on the theatre, stated that he considered it the city's duty to produce the work. In 1890, however, an extra cost of 6.000 Mark meant an increase of the annual municipal subsidy of about fifteen percent. During the period of leasing the theatre costs were held in check by the contracts with entrepreneurs, but with the city conducting its own artistic policy nothing stood in the way of extra spending. A mixture of artistic and local pride was time and again invoked to justify increasing the budget. This was Strasbourg and not just any local provincial theatre. Brazen declarations about an alleged superiority of German culture were never used, though they might have played a role as well.

Initially the city's subsidy of the theatre had been quite evenly matched to other major sources of income. The theatre received 20.000 Mark each year of the Apffel Foundation that had been created in 1847 by Jean Louis Guillaume Apffel to promote and support the art of music in Strasbourg. ${ }^{26}$ In addition 40.000 Mark was granted each year by the 'Statthalter' from 1888 onwards. The latter, however, came with three stipulations. The city had to continue its direct control, next to an ensemble of actors it now also had to engage and employ a corresponding number of singers needed for the production of large operas and when programming guest performances it had to bring primarily those of other German theatres. ${ }^{27}$ The first two conditions proved to be of pivotal importance. The first effectively forced the city to turn the temporary measure of running the theatre into a permanent one. If the rebuilding of the ancient theatre had been something of an architectural Trojan horse, the second proviso was its financial equivalent. Although 40.000 Mark was a substantial sum, the amount was soon dwarfed by the cost to the municipal authority needed to meet this condition. Indeed the spending started right away: recognizing that until then large operas had not been considered for performance, the municipal council immediately spent 17.000 Mark on new staging materials, costumes and improved lighting for Lohengrin, Die Walküre, Rienzi, Aida and Der Prophet.

The financial results of these politics speak for themselves. In the year the city took

\footnotetext{
${ }^{26 .}$ Geneviève Honegger, Le conservatoire et l'orchestre philharmonique de Strasbourg. (Strasbourg: Oberlin, 1998), 13.

27. Meeting of the city council, 18 July 1888; SMA 180MW, Nr. 3.
} 
over, the theatre had an annual budget of about 160.000 Mark, with a municipal subsidy of 30.000 Mark. $^{28}$ During the season that saw the first performance of Parsifal, the theatre's budget was 662.655,51 Mark, with a municipal subsidy of 213.471,76 Mark. (These expenses did not include the cost of the municipal orchestra.) Not only did the city pay more for the theatre each year, its contribution also accounted for a proportionately steadily increasing part of the budget, from less than $20 \%$ in 1888 to almost $30 \%$ two decades later.

The minutes of the theatre committee give further clues as to how spending got out of control. Whenever the theatre director argued that he needed more money for new productions, the committee would respond with some reluctance and ask for further specifications. In the end, however, such requests were almost always granted. Always seemingly short of money, the theatre was in fact rather well off. With Parsifal the same thing happened. When in the spring of 1913 Pfitzner mentioned that he wanted to perform Parsifal in the next season, the committee declined to make a decision, wishing instead to see an estimate of the cost. ${ }^{29}$ Soon afterwards, the municipal council agreed to a surplus expense of 25.000 Mark. ${ }^{30}$

Of course, there were other reasons as well for the ever increasing costs. The destruction of the original building had also meant the loss of its library and stock of sets and props. In an attempt to remedy the situation the city, together with Alexander Hessler, the theatre's director at the time, had bought a collection of plays, music materials (scores and parts) and stage props from a former theatre director, Franz Thomé. Thomé had worked in Linz, Riga, and Prague - where a young orchestra player, Antonín Dvořák, wrote his name and the dates of the performances in his viola part. ${ }^{31}$ For a total sum of 49.629 Mark, 12.000 Mark of which was provided by Hessler, the city became the owner of the texts and scores, whereas Hessler became the proprietor of the prop collection. A quick glance at the list of the scores reveals that the acquisition could hardly be used, consisting mostly of works that at the time of purchase were considered old-fashioned and

\footnotetext{
28. All figures, unless stated otherwise, are taken from the annually published 'Haupt-Budget' and 'Ergänzungs-Budget' (main budget and additional budget). The only surviving copies, unfortunately incomplete, are preserved in the Strasbourg Municipal Archive, where they still await cataloguing.

29. Meeting of the theatre committee, 9 April 1913; SMA 180MW, Nr. 26.

${ }^{30 .}$ Meeting of the city council, 2 July 1913; SMA 180MW, Nr. 98.

31. The contract, dated 3 July 1877, has been preserved in SMA 180MW, Nr. 301.
} 
had long fallen from the repertoire. ${ }^{32}$ Since Hessler had obtained ownership of the prop collection and took it with him when his contract expired, the city had to rebuild an entire stock of stage materials from scratch. This explains some of the high expenses.

Most of all, hiring a proper staff of opera personnel caused the biggest increase in costs. During the 1887-1888 season out of a total budget of 162.658,52 Mark, 128.030,97 Mark was spent on personnel; 28.934 Mark on opera singers, 26.921,16 Mark on actors and $27.743,82$ on technical staff, the remainder going to the choir, ballet, the director and the conductors. Whereas the salaries for the actors remained relatively stable over the yearsthe best paid actor, normally the 'Charakterspieler', earned something in the region of 400 to 500 Mark per month ${ }^{33}$ - the costs for the singers soon took off to unprecedented heights, with, no surprises there, the tenors and sopranos leading the way. In the season 1913-1914 the figures were as follows: 146.641,34 Mark for singers, 68.855,85 Mark for actors and 101.690.90 Mark for technical staff on a total sum of 331.636,04 Mark spent on wages. So whereas the cost for singers and technical staff accounted for $44 \%$ of the personnel budget in 1887-1888, in 1913-1914 together they took a chunk of nearly $75 \%$ of the same. (For the singers alone the figures would be $23 \%$ in the former and $44 \%$ in the latter season.)

Fortunately the city could also count on the income from the box office. ${ }^{34}$ During the early years the system of pricing had been relatively crude. There were three categories: A, $\mathrm{B}$ and $\mathrm{C}$. In the first and most expensive category prices ranged from 5 Mark for the best boxes to 45 Pfennig for standing room in the gallery. Prices in the B category were reduced by $25 \%$, whereas in the final category all tickets cost 1 Mark or 50 Pfennig for the cheapest places. The different price levels were not exploited with great regularity. Out of 170 performances during the season 1888-1889, the first year for which detailed box office records have survived, only 29 were priced in category B and a mere five in category C. Over the years a more sophisticated system was developed with different price levels, which were used much more frequently. During the 1913-1914 season six were

\footnotetext{
32. The collection was rediscovered by chance during the late nineties in the attic of the theatre and is at present stored in its basement in less than perfect circumstances.

33. Figures based on the salary lists in SMA 616MW, Nrs. 124-147. Salary was only paid during the eight months of the theatre season (mid-September to mid-May). During the remaining four months the personnel was expected to find other income or live off savings made during the season.

34. Figures based on the daily box office reports, preserved from the period 1888-1939, albeit with some gaps; SMA 616MW Nrs. 18-54.
} 
used: 'Gewöhnliche Preise' (7 Mark to 60 Pfennig), 'Opernpreise' (8 Mark to 60 Pfennig), 'Mittelpreise' (4,50 Mark to 50 Pfennig), 'Kleine Preise' (3,50 Mark to 40 Pfennig), 'Erhöhte Preise' (10 to 1,75 Mark) and 'Schülerpreise' (1,20 Mark to 60 Pfennig); the last was only used for special school performances. As these figures suggest, the bulk of the difference concerned the better seats in the house, with less variation for the inexpensive ones.

Although exploited with more variation in later years in order to lure people to the theatre, the effect remained negligible. During the 1888-1889 season the theatre collected 69.483,87 by box office sales, 15.448,50 Mark through subscription and a further 38.448,43 Mark from tickets with special reductions. The total sum, 123.380,80 Mark, constituted more than half of the total income of 240.855,92 Mark, producing an average box office receipt of 725,77 Mark per performance. The 1913-1914 season produced a total box office income of $303.315,36$, which made up only $45 \%$ of the total income but increased the average per performance to 1.180,22 Mark.

The increased use of raised prices was doubtlessly responsible for this result. Normally raised prices were used only for the six to eight French-spoken performances allowed per season or for productions with famous guest stars. When that happened to be somebody of world fame the already raised prices were raised even more. The absolute record was set during the 1902-1903 season, when the arrival of Sarah Bernhardt prompted the prices to go up to 30 Mark for the best seats to 1,50 Mark for a seat on the balcony. The proud second best was none other than the Strasbourg premiere of Parsifal, when prices ranged from 20 to 1,50 Mark. With a sold-out house the box office noted a receipt of 6.624,91 Mark, the absolute record for an opera performance without famous guests. As was the custom for evenings with high prices, no exception was made for holders of season tickets, thereby improving the possibility to really cash in on the occasion. The next two performances also brought in more than 6.000 Mark each, after which repeat performances with only moderately raised prices, ranging from 12 to 1 Mark, combined with admission for season ticket holders, managed to bring in amounts well over 2.000 Mark. Although more modest than the preceding performances, this was still much more than the takings on any average opera night. Parsifal cost big money, but this was one of the rare occasions where the surplus expense was matched by the box office result. 


\section{Fourth Vignette. People: Audience and Artists}

Two days before the Strasbourg premiere of Parsifal, Pfitzner held a lecture, Der Parsifalstoff und seine Gestaltungen. ${ }^{35}$ It was a rather unusual undertaking for him. Although well-read and endowed with a detailed knowledge of especially the German classics that filled those who knew him with admiration, he had never shown great interest in medieval literature, nor studied it. Pfitzner started with the remark that his lecture should in no way be considered an introduction to the performance, nor was it a necessary aid to fully understanding Wagner's swan song. The true work of art, he argued, is always selfsufficient: a vivid organism that contains all the clues needed for its comprehension. So if the whole exercise was futile with regard to the actual performance, why did Pfitzner feel the need to dabble in literary history? The answer was most likely that he wanted to strengthen the ties with his audience, more particularly with the university professors who constituted his most sympathetic supporters. Having been awarded an honorary doctorate at Strasbourg University the year before, Pfitzner apparently felt the need to repay the compliment by a quasi-intellectual contribution. ${ }^{36}$ We may safely bypass his address, a mixture of comparisons of earlier versions, with some references to Wagner's text, based on then recent scientific literature that, as Pfitzner warmly acknowledged, had revealed the deeply and purely Aryan roots of the Parsifal saga. What is more interesting about his lecture is that it provides us with a few clues about the makeup of the audience.

Although the archive of the theatre contains a wealth of material, it provides little or no clear-cut data about the public that visited the theatre. (Some contemporary research of its social, educational and professional background has only been preserved from the Nazi years.) The university, itself a product of the ambition to Germanise the 'Reichsland', did seem to provide a stable audience. More generally, the upgrading of Strasbourg to a regional capital seems to have had a favourable effect. When in the early thirties the theatre suffered a severe crisis, a list of 'Vital questions' was compiled, one of which was why the higher priced seats remained empty almost throughout the season. The answer was that the pre-war social stratum that considered visiting the theatre an indispensable habit had

\footnotetext{
35. Published in Hans Pfitzner, Gesammelte Schriften (Augsburg: Filser, 1926), I, 145-184.

36. See also John Craig, Scholarship and Nation Building. The Universities of Strasbourg and Alsatian Society 1870-1939 (Chicago: University of Chicago Press, 1984), 190.
} 
changed. High public officials, judges, attorneys, professors and military officers were sorely missed from the audience. ${ }^{37}$

During the first Parsifal productions it was essentially this audience that showed up. Various reviews paid attention to the dazzling display of fine uniforms with shiny ornaments and medals, classic dark evening attire and the lovely white and lilac dresses of the many young ladies. ${ }^{38}$ When prices were lowered after the first three performances, Otto campaigned to show Parsifal on Sunday afternoons. The well-off had already seen it, he argued, so now it was time to target the middle stratum. These people mostly had businesses of their own and would not be inclined to close earlier just to get to the theatre on time. Therefore a piece lasting some five hours could not successfully be scheduled as an evening performance, an argument sustained by the theatre committee and Pfitzner. ${ }^{39}$

Cheaper seats were presumably more popular with the lower middle class, but one can only guess. Sometimes the less well-off could use season cards from their employers. The psychiatrist Robert Wollenberg, a Strasbourg supporter of Pfitzner, describes this practice in his memoirs, but the reactions he recorded from his friends suggest that it was somewhat unusual. $^{40}$ Different social strata may have visited the theatre, but mingling was not appreciated and could lead to complaints. One member of the theatre committee even protested in writing against 'three ladies in conspicuous dresses', who had entered the first circle during intermission, without having seats there. Such behaviour, he opined, could scare off better situated families from visiting the theatre. ${ }^{41}$

Pfitzner certainly enjoyed enthusiastic backing from part of the audience, but he mostly inspired deep divisions within both the audience and the personnel. No record of his Strasbourg period seems to be complete without pointing this out. At least he initially enjoyed a good working relationship with Wilhelmi. The latter's style of directing the theatre was based on order and discipline, which, as he explained in a long letter to Schwander, to his mind was the indispensable corner stone of every truly artistic

\footnotetext{
37. 'Vitale Fragen des Stadttheaters', 5 December 1933; SMA 180MW, Nr. 11.

38. Straßburger Post, 12 January 1914. Similar remarks were made after the second performance; Straßburger Bürgerzeitung, 19 January 1914.

39. Otto to the theatre committee, [March] 1914; SMA 180MW, Nr. 15.

40. Robert Wollenberg, Erinnerungen eines alten Psychiaters (Stuttgart: Enke, 1931), p. 125.

41. Dammron to Zimmer, [1905]; SMA 180MW, Nr. 13.
} 
enterprise. ${ }^{42}$ Occasionally, however, he appears to have administered his medicine with such vigour, that it earned him a reproach from Schwander for the demeaning and insulting way in which he addressed his staff. ${ }^{43}$ Things really went awry with the arrival of Wilhelmi's successor, Anton Otto. His views on theatrical business differed profoundly from all Pfitzner stood for. According to Otto, the theatre should primarily offer entertainment, especially 'in this turbulent day and age'. Having thus been won over for regular visits to the theatre, the public would then also develop a longing for more serious performances. ${ }^{44}$ He therefore argued that he would primarily stimulate the production of appealing operettas, exactly the genre Pfitzner hated more than anything. "If I could have my way", he once declared before a delegation of the municipal council, "it would no longer be possible to show Parsifal on Sunday and Das Musikantenmädel on the next Monday." 45 Unfortunately for Pfitzner, and maybe also unknown to him, Schwander completely agreed with Otto's views. ${ }^{46}$

Yet Schwander seems to have hired Otto because he considered him the best candidate to protect Pfitzner. In 1918, looking back on his years in Strasbourg, Otto wrote that Schwander had told him right away: "I'm not interested in your artistic ideas. I need you as a diplomat." When he asked what he was to make of that, Schwander had simply retorted: "You'll find out soon enough". ${ }^{47}$ As a diplomat, Otto failed glaringly. He considered Pfitzner unhelpful and saw the latter's preparation for Parsifal as just another example of his impractical work method. He remembered it thus:

"On 16 August [1913] annual choir practice began. The choral conductor, Dietsch, came to my office and asked: "Mr. Director, what repertoire should the choir study?" "Well, didn't the opera director give you any orders?" "Nothing I know of." Mr. Pfitzner was in Hohwald, enjoying the freshness of summer. I therefore commanded him to rehearse the old operas that had been scheduled, as well as the

\footnotetext{
42. Wilhelmi to Schwander, 21 May 1912; SMA 180MW, Nr. 33.

43. Schwander to Wilhelmi, 28 October 1912; SMA 180MW, Nr. 33.

44. Otto to Schwander, 29 April 1913; SSA 180MW, Nr. 15.

45. Meeting of the four main committees; 11 May 1914; SMA 180MW, Nr. 70. Pfitzner referred to the performances of Sunday 12 April 1914 (Parsifal) and Monday 13 April 1914 (Das Musikantenmädel).

46. Schwander to Otto, 9 May 1913; SMA 180MW, Nr. 15.

47. Memoir by Otto, [January 1918]; SMA 180MW, Nr. 164.
} 
new productions planned by Mr. Pfitzner, Glöckchen des Eremiten, Schmuck der Madonna, Orpheus and the new operetta Hoheit tanzt Walzer. This was done for a week, when a letter arrived from Pfitzner, ordering us to leave all that and to rehearse solely Parsifal, which had been planned for January 1914 soon after the expiration of the performance restriction. Now the chorus only sang Parsifal for a fortnight, the opening of the season neared and now we had to arrange for the necessary opera productions head over heels. The consequence was not only that three weeks had been lost, because come January the choir had already forgotten Parsifal, but also that none of the schedule agreed to in May [1913] could be upheld. ",48

Soon afterwards Otto found out that Pfitzner was not prepared to accept even the slightest infringement upon his authority. Otto had ordered the schedule of the operatic season to be rearranged, but had insisted that Pfitzner be contacted to seek his agreement.

"That afternoon the phone rang. Pfitzner was calling. "Did you order that Undine be taken off the schedule?" I said yes and tried to start an explanation, but he shouts "Enough!" and hangs up. That evening, during the performance, I received a note from the mayor, that Pfitzner had requested to be discharged of his duties."

To be sure, Otto made matters worse by openly giving vent to his discontent, touching upon a sore spot for the committee. Rivalry and artistic differences might have been part and parcel of theatrical practice, but it was of paramount importance to the committee that such matters did not get out in the open. After all, the theatre was now a completely municipal institution and the population should not have the impression that its tax money was spent on establishment of doubtful reputation. In particular the suspicion of moral laxness, associated with theatrical practice since time immemorial, should be suppressed at all cost. In 1908 the committee had discussed complaints about private parties, where artistic personnel allegedly had taken part in entertainments of a smutty nature. ${ }^{49}$ Such

\footnotetext{
48. Ibidem.

49. Meeting of the theatre committee, 5 December 1908; SMA 180MW, Nr. 24.
} 
behaviour was condemned, but powerless to intervene without more accurate knowledge, the committee merely voiced the not overly realistic hope that those who organized such parties would in the future refrain from doing so. When the committee could act, however, it stopped at nothing.

Somebody who found out just how far the committee could go was Joseph Engel, the director from 1900 to 1903 , who had a reputation of being a ladies man. One committee member got wind of an affair he had had with Frieda Müller, a 22-year old woman, who had worked as a volunteer extra in the hope of being admitted to the ballet personnel. Together with a member of the chorus he pressed her into making a statement, threatening a month's imprisonment if she would not comply. The statement immediately ended Engel's Strasbourg career. Müller testified that Engel had told her to come to his home. There he had made her undress, to see if she had the legs of a prospective dancer after which, she stated, "he used me sexually". ${ }^{50}$ She also confessed to other sexual encounters with Engel in the box of the imperial governor and remarked that she had allowed them in the hope of furthering her career. In a vain attempt to diffuse the situation, Engel then dragged her to another attorney, where she claimed to have had just one sexual encounter with Engel in the theatre, but not in the box of the imperial governor-hardly a mitigating circumstance for Engel - and accused the singer who had pressed her into making the first statement, with whom she had had an affair previously, of having attempted to rape her. ${ }^{51}$ The errors in her first statement, she stressed, had been caused by her fear and confusion.

This may have happened many years before Pfitzner started working in Strasbourg, but the incident reveals that when any such suspicions arose the members of the committee were unforgiving. Furthermore, the affair had an unfortunate parallel with Pfitzner, because he too was accused of having affairs, albeit not with personnel from the theatre but with female students of the conservatory. When confronted by Schwander with these allegations, Pfitzner denied them emphatically. ${ }^{52}$ Indeed, there is no evidence to substantiate these accusations, but they stuck-surfacing, for example, in the correspondence between Strauss and Hofmannsthal ${ }^{53}$ —and when Pfitzner offered his

\footnotetext{
50. Statement by Frieda Müller, 2 October 1903; SMA 180MW, Nr. 33.

51. Statement by Frieda Müller, 9 October 1903; SMA 180MW, Nr. 33.

52. Meeting of the four main committees; 11 May 1914; SMA 180MW, Nr. 70.

53. Strauss to Hofmannsthal, 16 June 1927. Strauss proposed to Hofmannsthal to write a libretto featuring
} 
resignation in 1916, having not been offered a renewal of contract as opera director, the ensuing debate clearly illustrated that for some members suspicion about Pfitzner's morals had influenced their decision not to back him. ${ }^{54}$

It was bad enough that Pfitzner's personality earned him much enmity, but even worse that his working method occasionally produced the same results. He had insisted that for his productions the main roles should have double casts, but had not bargained for the jealousy that ensued between singers, who were not prepared to share roles they considered their own. The problem was solved by the committee, which after a few years abandoned the whole idea, considering it too expensive. That, of course, did not bring an end to the quarrels over the distribution of roles. Baritone Gustav Schützendorf argued with Schwander that he should have been given the part of Amfortas. Everywhere, he claimed, the lyrical baritone sings this part, whereas he had to be content with the role of Klingsor, which he considered too low for his voice. ${ }^{55}$ Eyebrows were also raised when the part of Parsifal was allotted to Max Hofmüller. Comparing his qualities to those of his colleague Fritz Bischoff, Otto remarked that Hofmüller had neither the voice nor the physical appearance required for a heroic tenor. Ticket holders regularly inquired at the box office and the theatre's bureau why Hofmüller was singing instead of Bischoff. The latter's corpulence did make him less suitable for certain parts but, as Otto remarked dryly, the same applied for the other tenors engaged at the time. With his fine warm voice, Bischoff was Otto's candidate for the role of Parsifal, but he acknowledged that in the end Hofmüller had the more appealing stage appearance. ${ }^{56}$

Every picture of the professional atmosphere in the Strasbourg theatre can only be based on the few, not necessarily complete sources that have been preserved. However, when there is a grain of truth in the almost continuous stream of maliciousness and acrimony that has been recorded in the theatre's archives during the years that Wilhelmi,

three types of composers, a German bohemian, a universal genius, like Mozart, and 'the so-called Krautfigure, like Marschner and most characteristically Pfitzner, [praised] by the German nationalists as the prophet of the "German soul", the last poet of German forest and meadows romantics, but inwardly a shabby character, full of petty jealousy, whose wife, who he has cheated with Christinas and conservatory girls, delivers a eulogy in verses at his grave'. Willy Schuh, ed., Richard Strauss-Hugo von Hofmannsthal. Briefwechsel (Zürich: Atlantis, 1978), 573.

54. Meeting of the four main committees; 10 March 1916; SMA 180MW, Nr. 70.

55. Schützendorf an Schwander, 3 January 1914; SMA 180MW, Nr. 165.

56. Otto to the theatre committee, 18 October 1913; SMA 180MW, Nr. 99. 
Pfitzner and Otto worked there, then there can be no doubt that the artists involved in the first Strasbourg performance of Parsifal, a work celebrating the power of purity and the glory of redemption, were really just acting that message.

\section{Fifth Vignette. Performance: Principles and Freedom}

Pfitzner had very specific ideas about performing. He wrote an entire book on the subject, Werk und Wiedergabe, first published in 1929. His thesis held that a performance should never be an interpretation but a rendering, based on the authorized score and the indications provided there. He would have fumed at the idea that his productions might also be called interpretations, which, of course, they were. Not to him, however. Even his adaptations of Marschner operas were, in his mind, not interpretations but corrections, dictated by what he called 'die Wille zum Werk', the resolve to reproduce an artwork by completely complying with the artist's intentions, even if this meant reworking the original. This was acceptable when elements were removed, that for one reason or another failed to realise the intended artistic conception.

To his mind any convincing operatic production could only come from complete unification of all aspects involved, making the conductor/director the translator of the unity already present in any work of art that possessed real value. If interpretation were needed, then it would merely prove that the artwork was not fully capable of communicating its content. To ensure that in Strasbourg such unity characterized his productions, he controlled every aspect. This philosophy was also the driving force behind the opera class he had founded at the conservatory. It was meant to be a 'Stilbildungsschule', modelled after the concept Wagner had described in his concept for a new music school in Munich. ${ }^{57}$

Pfitzner sought to guarantee the artistic quality of his productions by using double casts and having all involved attending the rehearsals, also the junior conductors and directors who would be in charge of the performances that would take place in Pfitzner's absence. ${ }^{58}$ He ardently denied that his method would be a straightjacket for the performers, arguing that conforming to the intentions and the spirit of the work did not mean that one had to

\footnotetext{
57. Pfitzner to the theatre committee, 24 March 1912; SSA 180MW, Nr. 71.

58. Hans Pfitzner, Werk und Wiedergabe, Gesammelte Schriften 3, 158-159.
} 
give up one's individuality. In addition, following the intention of the work would free the performer from supposedly authorized traditions, which more often than not, were completely unreliable and based on misunderstandings.

The concrete realization of these ideals, as far as opera production is concerned, can be witnessed from the notes he made in piano reductions when preparing a performance. Quite a few have been preserved, but unfortunately his copy of Parsifal has but very few such annotations. As is customary with such notes, these are mainly limited to a few indications for movements. ${ }^{59}$ We therefore mainly have to rely on reviews of his production. A happy circumstance is that a few sketches for the sets of this production have been preserved, giving us some further insights into the production. ${ }^{60}$

Not even they had been left out by Pfitzner's wishes for a unified style of performance. They were painted by Georg Daubner, who in 1908 had been given a studio of his own by the city in acknowledgement of his work, which had favourably impressed the press, the audience and the theatre's director, Wilhelmi. Before starting on the Parsifal sets, Daubner received a visit from Pfitzner, who told him in detail what he wanted. He illustrated his desires by playing excerpts from the opera on the piano, thereby not limiting himself to giving instructions, but also seeking to inspire Daubner. ${ }^{61}$ The latter apparently reminisced enthusiastically about this experience in later years, claiming that no one before had heightened cooperation to such a level. It was not the only thing that created a bond between him and Pfitzner. In his sole and rather short publication on the art of painting stage canvases, he presents himself as a stickler for exactly the sort of verisimilitude that Pfitzner used to advocate. ${ }^{62}$

\footnotetext{
59. Munich, Municipal Music Library; Pfitzner Collection.

60. Preserved in the Musée d'art moderne et contemporaine, Strasbourg; no signature. Unfortunately none of Daubner's sketches for the Grail temple seem to have been preserved.

61. Martin Spahn, 'Zur Berliner Pfitzner-Woche. Straßburger Erinnerungen', Süddeutsche Monatshefte 24 (1926/1927): 239-241.

62. Georg Daubner, 'Über Bühnenmalerei’, Das Kunstgewerbe in Elsass-Lothringen, 7 (1902): 121-130.
} 
The following sketches can be identified as the first scene of Act One (nr. 1), Klingsor's magic castle (nr. 4), the magic garden (nr. 5), the wasteland (nr. 6) and the opening scene of the last act (nr. 7), the flowery meadow with Gurnemanz's cabin on the left. Of nr. 3 two water colours survive, the second being somewhat less vivid in the display of flowers (during the performance the bright colours were toned down anyway by lowering a veil in front of it, a usual procedure for indicating a magical atmosphere). Furthermore, sketches in black and white, some made with ink, some with crayon, have been preserved of nr. 1, 5 and 7. Somewhat puzzling is another sketch, titled 'Forest' (nr. 2), and a further water colour with two corresponding sketches (nr. 3). These were probably used for the transformation in the first scene.

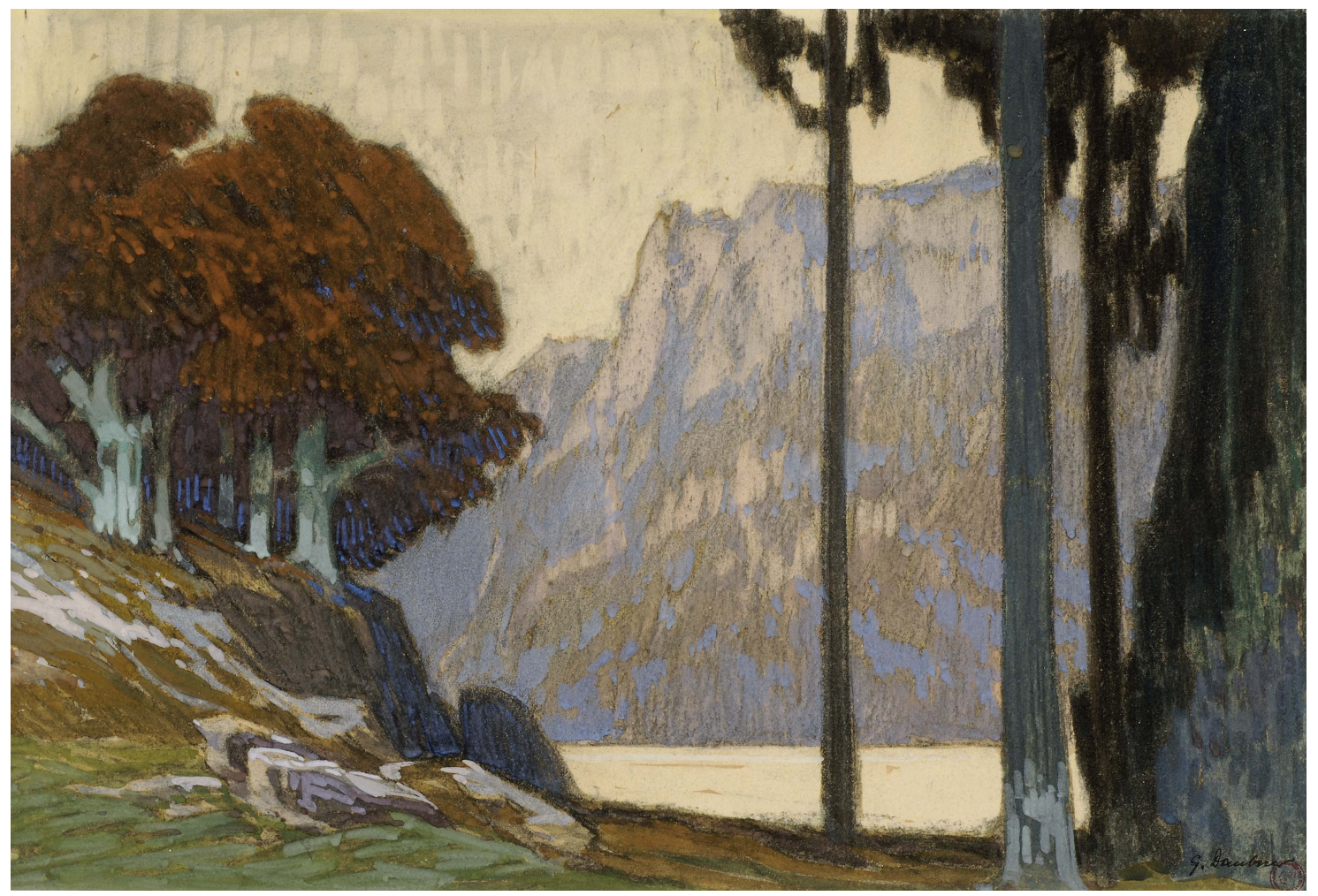



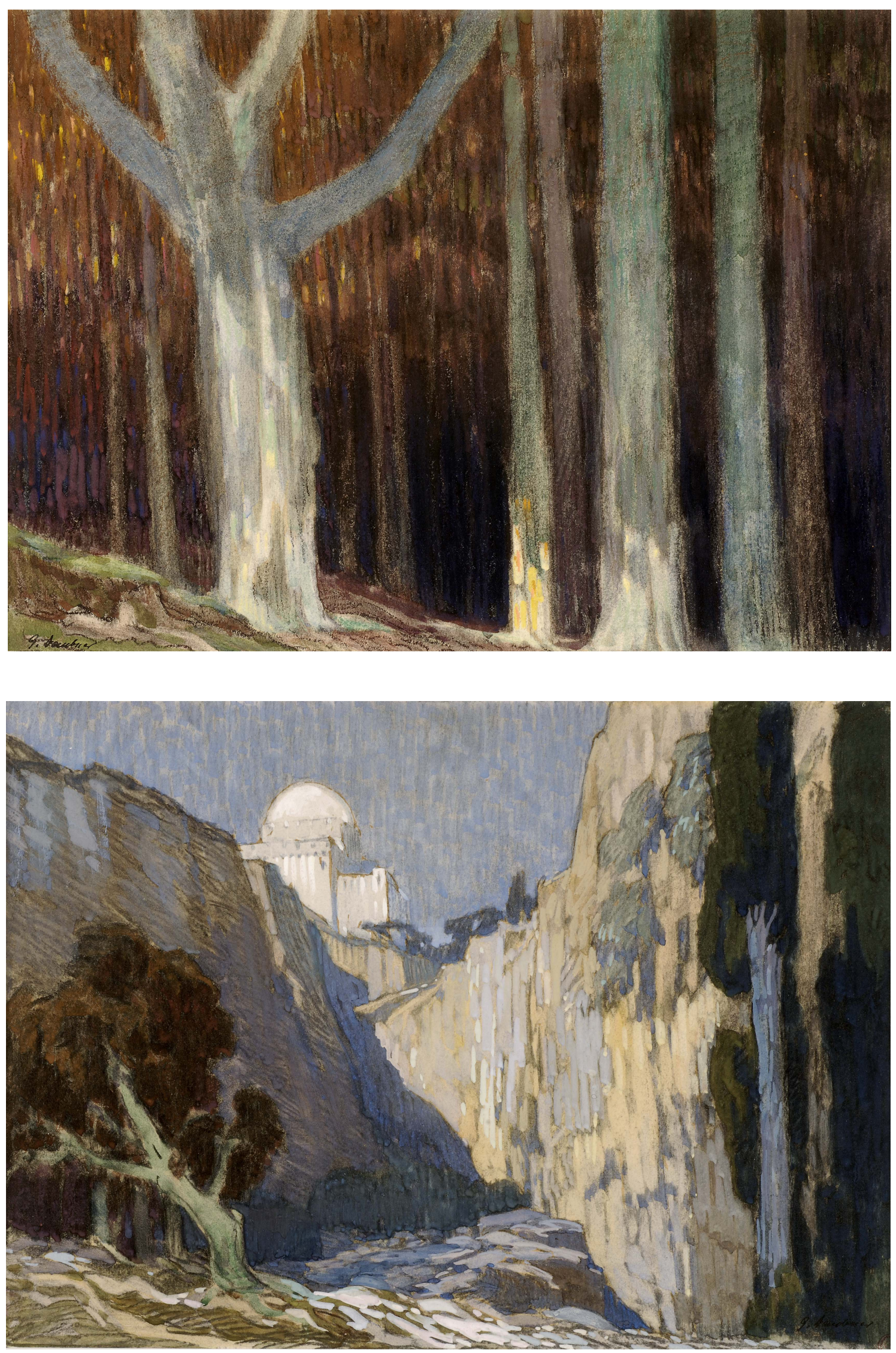

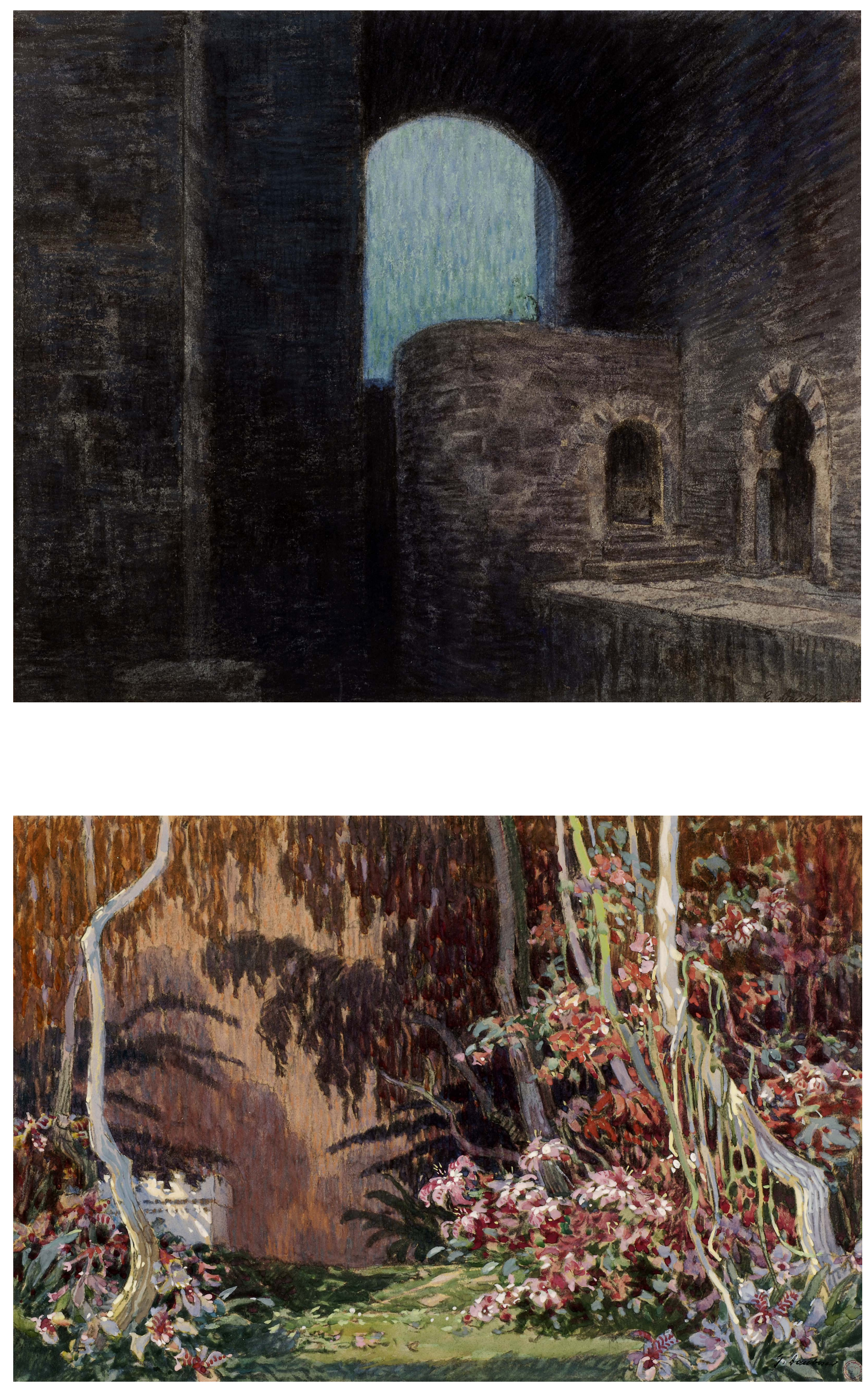

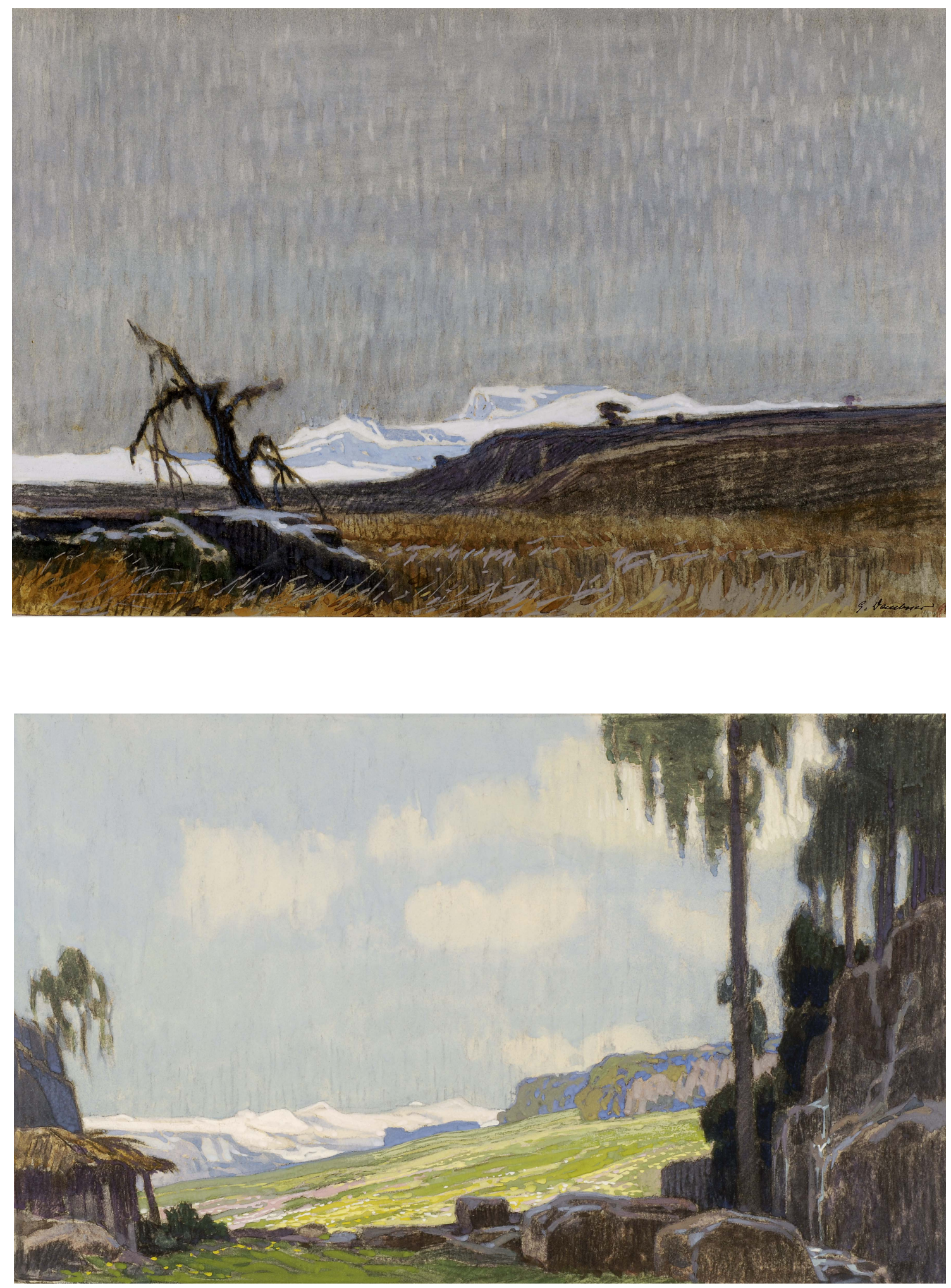
Conclusions can only be drawn from these sketches with some apprehension; they might have been less detailed than the final product and would in any case have been adorned further by stage props. Yet on the whole, especially when compared to the sets used for the Bayreuth premiere in 1882, they are characterized by sparseness and evoke a sense of serenity through its large planes and the dominance of a single colour. ${ }^{63}$ Klingsor's castle makes a daunting impression, suggesting something supernatural by its bleakness rather than actually showing the usual witchcraft-like attributes. (The complaint of one critic confirms that it was not decorated with additional props. ${ }^{64}$ ) Most surprising of all is probably the wasteland, which articulates an arid loneliness lacking in the Bayreuth version. Keeping true to the score alone apparently did allow for freedom of interpretation, ignoring a so-called authentic tradition and bypassing certain details, like the castle in the magic garden, which has nothing of the rich Arabic ornamentation prescribed by Wagner.

In certain aspects the Strasbourg performance was no match for the Bayreuth original though. Parsifal calls for four large scale transformation scenes: (a) from the forest into the Grail temple, (b) from Klingsor's castle into the magic garden, (c) from the latter into the wasteland and (d) from the meadows into the Grail temple again. According to the comprehensive manual compiled by Friedrich Kranich in 1929, until the early nineteentwenties the first and the last had to be achieved through a 'Wandelbild', a transforming set, or in fact a number of sets, painted on a single canvas, which was then rotated slowly horizontally, thus enabling one set to emerge when the previous one slowly disappeared from sight. The second and third transformations had to be realized by machinery; the former in the dark, the latter on an amply-lit stage. ${ }^{65}$ In Strasbourg none of this could be done. There was no equipment for submerging sets or slowly raising them from under the stage, nor could such an apparatus be installed easily, because, despite repeated warnings from the fire brigade, all space below stage had been cramped with sets and props for which no other storage room was available.

Some clues to Pfitzner's solutions can be found in the various reviews, especially in the

\footnotetext{
63. For (black and white) reproductions of the Bayreuth sets, see Dieter Mack, Der Bayreuther Inszenierungsstil, 100 Jahre Bayreuther Festspiele 7, (München: Prestel-Verlag, 1976), plates 42-47.

64. G. Altmann, 'Parsifal', in: Straßburger Post, 12 January 1914.

65. Friedrich Kranich, Bühnentechnik der Gegenwart (München/Berlin: Oldenbourg, 1929), I, 258.
} 
rather detailed assessment in the Elsass-Lothringische Musikzeitung. ${ }^{66}$ It appears that for some problems rather crude solutions had been chosen. The wasteland was simply a new background, lowered in front of the magic garden. In the third act the inevitable had been accepted: the main curtain was lowered, after which the grail temple reappeared. In the first act however, Pfitzner had created a successful solution for the transformation. A black curtain was moved slowly from left to right. Parsifal and Gurnemanz would wander over the stage just in front of it, focussing attention on the black curtain. While they were moving along, a new background was lowered. When the black curtain finally disappeared out of sight, the new background revealed that they had progressed on their way to the temple. Using the information from two reviews, it appears that this was repeated twice and that may account for the last two sketches, Nrs. 6 and 7, illustrating the journey, following which the grail temple was shown after the third time the black curtain had been used.

Pfitzner's conducting was generally praised, without mentioning details. A single remark, however, highlighted the independence of his musical conception from Bayreuth traditions. With his performance lasting almost half an hour less than those in Bayreuth, Pfitzner had respected Wagner's intentions and avoided stepping in the Bayreuth performance tradition founded by Felix Mottl und Carl Muck. ${ }^{67}$ For the singers there was praise all around, especially for Wilhelm Wissiak, who had sung Gurnemanz, but luckily for all involved Schützendorf was acclaimed as well, just as Hofmüller's Parsifal. Pfitzner's methods might have been disliked, but his results were considered beyond reproach.

\section{Sixth Vignette. Press: Reviewing and Looking Ahead}

Whatever the controversy over Pfitzner might have been, it should not be forgotten that the theatre committee went along with payment for his work as opera director because of the almost unanimously enthusiastic reviews of his performances. Not even Schwander could

\footnotetext{
66. Recensions appeared on 12 January 1914 in Der Elsässer, Badische Volkszeitung, Straßburger Bürgerzeitung, Straßburger Post, Neueste Nachrichten, Neue Zeitung and the Journal d'Alsace et de Lorraine and in the Elsass-Lothringische Musikzeitung 8 (1914): 62-63.

67. Straßburger Post, 12 January 1914.
} 
have forced that decision on the committee alone and that illustrates the important role of the press.

When the city took direct control over the theatre, the press did not need long to figure out that their influence had suddenly increased. Any critical review had up to that point been nothing more than just a complaint about a poor performance. Now it could also be interpreted as an urgent call from the electorate to make better use of the taxpayer's money. When the director remained deaf to critical opinion, critics could divert their attention to the municipal council and the theatre committee. Both institutions were well aware of this. The minutes of the council meetings contain numerous statements from delegates assuring that in the future they would continue to read the reviews with close attention and act upon any complaint.

Sensitive handling of press matters had now become an imperative for all high profile theatre employees. Unfortunately, neither Pfitzner, nor Wilhelmi nor Otto excelled in this department. Otto occasionally wrote letters to the editor in response to criticism, but whatever sympathy it brought him in public was cancelled by the problems it caused him in the theatre. Pfitzner's inability to come to any understanding with the press was legendary and is still best illustrated by the public riot created by his alleged statement that Strasbourg's provincial artistic life was like a swamp. ${ }^{68}$ In fact, he probably never made that statement - even the journalist who had published it admitted that he had made up the 'swamp' himself. In the aftermath of the affair, however, Pfitzner unfortunately showed supreme skill in avoiding any kind of effective damage control, so that in the end, although not guilty of saying anything untoward about Strasbourg, his reputation suffered considerable damage.

Wilhelmi had been admonished time and again by the theatre committee to entertain a better relationship with the press, but he never seemed to understand in what key his communications were supposed to be. In 1911 he sent a press message to local newspapers about the forthcoming Strasbourg premiere of Pfitzner's Der arme Heinrich. The theatre, it read, had frequently received requests, especially from the fairer sex, to indicate well beforehand when festive performances would take place and thus give them the

68. For a discussion of the affair, see Walter Abendroth, Hans Pfitzner (München: Langen, Müller, 1935), 194-195. 
opportunity to dress accordingly. Acting upon these wishes, he now announced such a special performance, expressing his expectation that the audience would follow this cue. ${ }^{69}$ Three days later he received an angry letter from an irritated Schwander, who told him that an important theatre like Strasbourg had better not indulge in advertising like a screaming market salesman. ${ }^{70}$ Wilhelmi defended himself and pointed out that Pfitzner had agreed wholeheartedly with the notice and its content, after which Schwander relented somewhat, but not without advising Wilhelmi to adhere in future publications to the detached grandeur that fitted a municipal theatre. ${ }^{71}$

Just as with Pfitzner's Der arme Heinrich, the theatre surrounded the advent of the Parsifal production with a publicity campaign. Unfortunately no copies have been preserved of the season's brochures, which are as a rule the most revealing sources of the theatre's self-promotion, but various other small comments in newspapers clearly indicate that the theatre had not missed any occasion to proclaim Parsifal the prime attraction of the season. The local press also discussed the expiration of the Bayreuth 'Schutzfrist', the failed attempts to prolong it and the possible consequences of the loss of exclusivity. ${ }^{72}$ Further attention to Parsifal was created by the many summarized reviews from the first performances in other cities in Germany and Austro-Hungary. Recapitulations of Pfitzner's Parsifal lecture and another introduction, given by Prof. Friedrich Lienhard, an expatriate Alsacian poet, also found their way into the Strasbourg newspapers.

The theatre's office took precautions for a well-ordered handling of ticket sales, doubtlessly inspired by the somewhat clumsy way sales for high-profile productions had been organised in the past, when long queues in front of the theatre and the buying and reselling of tickets on the black market had necessitated police intervention. On 30 December 1913, the Strasbourg premiere was announced for 11 January 1914. Simultaneously procedures for ticket sales were announced. Tickets for the first and second circle could be ordered by mail beginning next day. All requests would be numbered and processed accordingly. Tickets for the third and fourth circles could only be

\footnotetext{
69. Straßburger Post, 7 January 1911.

70. Schwander to Wilhelmi, 10 January 1911; SMA 180MW, Nr. 15.

71. Wilhelmi to Schwander, 11 January 1911, Schwander to Wilhelmi, 23 January 1911; SMA 180MW, Nr. 15.

72. See, for example, 'Zur Befreiung des Parsifal', in: Straßburger neueste Nachrichten, 2 January 1914.
} 
purchased at the box office, starting on 5 January 1914 at $10.00 \mathrm{a} . \mathrm{m} .{ }^{73}$ A few days later the theatre office notified the public that the best tickets were by now sold out and further mail orders could not be considered. ${ }^{74}$ A further constant cause for annoyance, late-comers entering the auditorium after the start of the performance, was addressed in another separate notice, urging the public to observe that the doors would be closed at five p.m. and that entering at a later stage would be impossible, since there would be no pause between the orchestral prelude and the first act. In addition, the public was asked to appreciate the sacred nature of the work and to refrain from applauding until the final curtain. $^{75}$

Such attentive communication through the press was relatively rare and once more underlined the special nature of the Parsifal premiere. Yet this stream of orderly notices was punctuated by the more mundane press attention that constituted the steady number of letters to the editor. Mostly these were complaints about the lack of variety in the repertoire, occasionally related to the forthcoming Parsifal premiere. "We have been consoled by the theatre office time and again, that the unadventurous programming was caused by the necessary preparations for Parsifal, and now we are confronted with the news that the first performances are not even open to those with an annual subscription", one theatregoer complained. ${ }^{76}$ Less enjoyable for the theatre was the simultaneously continuing flow of commentaries on the conflict between Pfitzner and Otto, which by now had become public knowledge. ${ }^{77}$

Such writing was not considered particularly helpful. Schwander and for that matter the theatre committee as well, would have preferred to have some control over the press, although they realized that such wishes could never be realized. Unfortunately the relation between press and theatre, and consequently between press and municipal authority, always bordered on the vitriolic. The theatre committee time and again complained about the harshness of the reviews and pondered how the critics could be made to understand the

\footnotetext{
73. ‘Aus den Theaterbureaus', in: Straßburger neueste Nachrichten, 30 December 1913.

74. 'Aus den Theaterbureaus', in: Straßburger neueste Nachrichten, 3 January 1914.

75. 'Aus den Theaterbureaus', in: Straßburger neueste Nachrichten, 10 January 1914.

76. 'Einsendungen aus dem Publikum', in: Straßburger neueste Nachrichten, 3 January 1914. Further complaints can be found in the papers from 30 December 1913, 31 December 1913 and 6 January 1914.

77. See, for example, Straßburger Bürgerzeitung, 6 January 1914; Straßburger neueste Nachrichten, 7 January 1914; Freie Presse, 8 January 1914; Der Elsässer, 10 January 1914; Straßburger Bürgerzeitung, 13 and 14 January 1914.
} 
effort the city was making with the theatre. It would be wrong to assume that all reviews were bad or spiteful, but when there was reason for disapproval, it was voiced with a disparaging aggression that left municipal authorities desperate and that was a situation that outlasted the German period, continuing during the twenties and thirties and leaving the French authorities just as baffled and helpless as their predecessors. Not even the successful Parsifal performances were graced with overly friendly press coverage. True, the efforts of Daubner, Pfitzner, the orchestra and the soloists were generally applauded, but there was not a single review without a shot at the ridiculously antiquated machinery in the theatre. This was reviewing and simultaneously looking ahead for the next cause that cried out for remedy by the municipal authorities. The latter tried to do their best and placate and win over the press. It was therefore no coincidence that the final communication concerning the Strasbourg premiere of Parsifal was initiated by the theatre committee. Having received the financial report, which showed that the revenues had equaled the extra cost of 25.000 Mark, the theatre committee expressed its satisfaction and decided to publish this report. ${ }^{78}$

\section{Epilogue}

Having looked at Pfitzner's Parsifal production from six different perspectives we may attempt to draw some conclusions about the usefulness of breaking down daily operatic practice this way.

A significant advantage is the way in which operatic production may be integrated with its surrounding factors. Most histories of opera houses or of certain traditions of operatic production struggle with this, reducing them in fact to external factors that get short cameos whenever some discontinuity in the production schedule has to be explained. (Well-known examples are a lack of money or restrictions in repertoire choices imposed by some authority.) Such narratives tend to disregard the fact that such factors constitute ongoing influences, even when they are relatively unobtrusive, and should be treated as such, rather than as some sort of exterior force disrupting a supposedly independent artistic routine.

\footnotetext{
${ }^{78 .}$ Meeting of the theatre committee, 12 May 1914; SMA 180MW, Nr. 26.
} 
Another advantage of this method is that whilst it enables us to understand and to analyze which factors have an impact on operatic practice, it does not offer any kind of reductionist 'logical' explanation. Indeed, when different communication systems come into contact and disrupt established patterns of communication, the outcome is generally completely unforeseeable. This also holds true for this particular case study. It might be tempting to interpret Pfitzner's Strasbourg production of Parsifal as the logical outcome of the politics of 'germanisation' in the Alsace, but the facts do not support any such argument. Pfitzner had not been given the job of general opera director because he was a staunch defender of German culture - that may have been on Schwander's mind, but there is no document whatsoever that explicitly mentions his cultural nationalism as an argument in favor of his appointment. Nor was the 1916 decision by the municipal council not to extend his contract related to lack of achievement or to any changes in cultural politics. Instead, both decisions owed more to personal interaction, which demonstrates how patterns of personal communication may overrule more impassive business considerations. Mounting Parsifal in Strasbourg was not inspired either by the wish to transform the municipal theatre into a beacon of German culture on the French border; local pride was the prevailing argument here - as well as the primary cause for the budget getting out of hand soon after the municipal authority had taken full control of the theatre.

Finally, this method enables us to contemplate the complexity of opera production, whilst simultaneously reducing complexity: any system shuts out an overwhelming array of potential other decisions and possibilities, limiting itself to a certain type of communication. We are left with the relevant communication systems that actually affect operatic practice. This means that there is no need for an historical narrative that starts by painting a general background, some elements of which might be relevant for a certain opera production, and then confronts us with the cumbersome task of deciding when, where and how their relevance may come into play. If we limit ourselves to the systems immediately involved, we get a much more focused picture. The complexity of operatic production and the difficulty in unraveling the various factors involved, as demonstrated in Pfitzner's production of Parsifal, demonstrates that such an approach may be quite useful. 
This document was created with Win2PDF available at http://www.win2pdf.com. The unregistered version of Win2PDF is for evaluation or non-commercial use only. This page will not be added after purchasing Win2PDF. 